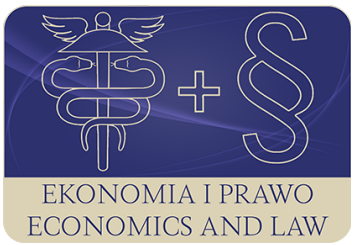

EKONOMIA I PRAWO. ECONOMICS AND LAW

Volume 20, Issue 2, June 2021

p-ISSN 1898-2255, e-ISSN 2392-1625

www.economicsandlaw.pl

EKONOMIA I PRAWO
ECONOMICS AND LAW

ORIGINAL ARTICLE

received 30.03.2021; revised 20.06.2021; accepted 30.06.2021

Citation: Kamińska, K. (2021). Systemic transformation in Poland and Eastern Germany: two versions of the Social Market Economy. Ekonomia i Prawo. Economics and Law, 20(2), 257-276. https://doi.org/10.12775/EiP.2021.015.

\title{
Systemic transformation in Poland and Eastern Germany: two versions of the Social Market Economy?
}

\author{
KATARZYNA KAMIŃSKA \\ SGH Warsaw School of Economics, German Economy Research Department, Al. Niepodległości162, \\ 02-554 Warsaw, Poland \\ 曰kkamins@sgh.waw.pl \\ (D) orcid.org/0000-0003-0497-7452
}

\begin{abstract}
Motivation: The process of systemic transformation in the countries of Central and Eastern Europe, including Poland and Eastern Germany, which began in the early 1990s, can be described as a unique event in the entire economic history of the world. Therefore, in a situation where it was necessary to decide on the model and pace of stabilization, it was difficult to refer to the experience of other countries. The 30 years that have passed since the beginning of the systemic transformation in Poland and East Germany have been a convenient time to assess the course of the transformation process, the changes that have taken place in these economies, and describe the economic models that have shaped them. The reason for this lies in the importance of this subject and the consequences which the countries of Central and Eastern Europe, including Poland and East Germany, continue to face. Parts of this paper were written as part of Statutory Research at the College of World Economy of the Warsaw School of Economics in 2020, 30 years after the system transformation: lessons and current challenges for the economy in Germany and Poland.
\end{abstract}

Aim: The article aims to compare the course and consequences of the systemic transformation in Poland and East Germany, highlight subconsciousness and differences, 
and determine to what extent the shape of the economic system meets the assumptions of the Social Market Economy.

Results: The primary added value of the article is a comparative analysis of the Polish and East German systemic transformation from the perspective of 30 years from its beginning, its successes and failures and a reference to the assumptions of the social market economy, as well as an attempt to answer the question about the contemporary character-

istics of both economies.

Keywords: systemic transformation; shock therapy; economic system; Social Market Economy; institutional framework

JEL: B22; B52; E02; E29; E65; P16

\section{Introduction}

The process of systemic transformation in the countries of Central and Eastern Europe, including Poland and Eastern Germany, which began in the early 1990s, can be described as a unique event in the entire economic history of the world. Therefore, in a situation where it was necessary to decide on the model and pace of stabilization, relating to the experience of other countries became a challenge. The fundamental problem of the transformation remains the appropriate choice of the target economic and political model. What is essential is to identify the avenues to reach it. In Poland, at the turn of the twentieth and the twenty-first centuries, there was a discussion on this kind of model for the Polish economy. A notion that emerged was trying to adopt a model of the Social Market Economy based on the experience of West Germany. In 1997 there was even a special provision in the Polish Constitution that stated that the Social Market Economy is the basis of the Polish economic system. However, the reality of the political transformation has moved away from this model and its assumptions and has remained the subject of debate until today. It should be underscored that its actual shape in 1990 differed significantly from the visions of the spiritual fathers of the SME (Social Market Economy). In the case of East Germany, the tried and tested and effective system of the Social Market Economy, with a stable currency, was transferred to the territory of the former GDR without a transition phase. The decision to choose precisely this economic and social model for East Germany was related to social issues (Kamińska, 2018. p. 257).

The thirty-year gap between the launch of the systemic transformation in Poland and East Germany and the beginning of the third decade of the twenty-first century has been a convenient time to assess the course of the transformation process, the changes that have taken place in these economies, and describe the economic models that have shaped them. The reason for this lies in the significance of this matter and the outcomes of the actions undertaken in Central and Eastern Europe, including Poland and East Germany, that the countries still have been facing.

This article aims to juxtapose the course and consequences of the systemic transformation in Poland and East Germany and differences, and deter- 
mine to what extent the shape of the economic system meets the assumptions of the SME. In both cases, the same model was chosen, but the routes to get there were different, and the outcomes of the process were surprising. When attempting to compare the transformation of East Germany and Poland, the following differences must be taken into account: Poland followed the path of shock therapy. Contemporaneously, the transfer of market institutions in East Germany was accompanied by financial support from the old federal states and the European Union. Thus, the transformation in this country was expected to be tranquil, and its social costs minimal (Maier, 2012).

Parallels have been constructed between crucial macroeconomic indicators for the two economies, along with the chosen institutional and legal frameworks underpinning the further development of the juxtaposed economies. As the notion undertaken in the study is complex and not amenable to econometric modelling, the qualitative analysis method of comparative analysis was implanted for analysis purposes. Moreover, as the subject under evaluation has its theoretical background, the method of the critical literature study was applied.

The article opens with the description of the theoretical issues of the economic transformation process, then identifies the main features of the social market economy model, which can be found in the literature review. Next, the research methodology is described, followed by a treatment on the results of the analysis of the transformation process and the features of the economic model of Poland and East Germany in the context of assessing the degree to which they achieve the features of a social market economy. The whole study is summed up by the final conclusions.

\section{Literature review}

There are English-language studies available on the subject regarding the notion of systemic transformation in Poland. The model of the Social Market Economy and the systemic transformation of the East German economy, on the other hand, is yet to be comprehensively addressed in English (one of few exceptions here is Maier, 2012). Therefore, this article contributes to infilling the current gaps in this respect.

The first theoretical issue in this part is the definition of systemic transformation. There is no consensus among economists when it comes to the definition of the notion. In the literature on the subject, one can only find statements indicating that the transformation is a change in the economic system consisting in the transition from a centrally planned socialist economy to a market economy of the capitalist type. Despite the passage of time, it remains one of the matters constantly put forward by economists. It should also be noted that the pundits addressing the issue, particularly in Poland, for years have been divided when it comes to assessing the course of the system transformation and its effects (e.g. Kołodko, 2000; 2020; Żukrowska, 2000). Throughout Central and Eastern European countries, the transformation model proposed 
by the International Monetary Fund was applied, which assumed macroeconomic stabilization and liberalization and far-reaching institutional reconstruction. The choice of the pace of change remained crucial. Following the criterion of frequency-occurrence in literature, one of the critical dilemmas that have been dividing economists is the matter of deciding on the pace of systemic transformation, also known as "shock therapy versus graduation" (Kołodko, 2000; Kouba, 2016). The radical model, called shock therapy, assumed an immediate change in the functioning of the economic system. It was supported by representatives of the Anglo-Saxon economy, including predominantly monetarists, D. Lipton and J. Sachs internationally, and Leszek Balcerowicz, W. Wilczyński and J. Winiecki domestically. The other direction was gradualist therapy, supported by V. Amiel, K. Grace and D.M. Nutti. In Poland this course of action was advocated by Z. Sadowski, J. Lipiński and G. Kołodko. In Poland, the dominant approach among economists was shock therapy, which later translated into the nature of the changes (Rosati, 1994; Sachs, 1993).

The second issue is the proper understanding of the Social Market Economy model as an economic model. The SME is a term to which numerous meanings are currently attributed. The key representatives of this concept are Alfred Müller-Armack and Ludwig Erhard. The architects of the theory in question themselves emphasised its syncretic nature. Ludwig Erhard described the social market economy as a synthesis of "economic freedom, the responsibility of economic agents and social equality" (Kaczmarek \& Pysz, 2004, pp. 111-112). According to Müller-Armack, SME is an attempt to form the possibility of a social idea that unites world views on the one hand and to grasp the social dimension of the economic order on the other. The latter gives an idea of how the recognition of freedom and social justice as fundamental values can be guaranteed within the framework of a free-market economy (Müller, 2019, pp. 47-48). The social market economy cannot be seen as an independent concept. It is to be understood rather as a programme that has developed within itself, which has its historical starting point in German neo-liberalism of the early 1930s and which, to a particular degree, is to be defined through its adaptability concerning the accompanying social, cultural and economic framework (Müller, 2019, p. 47). On the one hand, it is regarded as a concept of economic policy implemented in Germany by Ludwig Erhard between 1948 and 1966. On the other hand, the term functions as an idea of order, a particular way of thinking, a model of socio-economic policy, and a famous political slogan (Klump, 2001, p. 17).

Historically, the Social Market Economy has been linked to the Ordoliberal doctrine, which developed in German economic and legal thought. This link has been increasingly loosened over the years (Kamińska, 2018, p. 6). The SME can be seen both as a social idea in its own right and an integrative idea for humanising society through social structures geared towards reconciliation and peaceful mediation of conflicts (Müller-Armack, 1978, p. 173). The essential element of the synthesis of the social market economy is the principle of subsidiarity. It 
reflects the extent to which ownership is preferred to be granted concerning the state initiative (Müller, 2019, pp. 48).

The main assumptions of this doctrine can be pointed out: the rejection of central planning, treatment of the market and the existence of free competition as crucial elements of the economic system, determined fight against monopolies, legal determination of the scope of state intervention and competition, protection and safeguarding of private property, individual freedoms and giving the economy an ethical dimension (Zagóra-Jonszta, 1999, p. 17).

The most famous representative of the Ordoliberal doctrine was Walter Eucken. The ordoliberal school does not characterize a "strong state" as a state that intervenes decisively in the economic process, but as an effective framework, which sets the economic order, specifically, creates formal institutional conditions, under which the socio-economic process is free and a level playing field for the participation of all (Eucken, 1992; Karsten, 1985). According to Eucken (2004, p. 179), the order of competition is closely linked to economic order and creates a competitive economic order. The prices constitute the foundation for competitive economic order, the development of which should be governed by supply and demand laws. At this point, one ought to highlight the crucial role of legal regulations created by a neutral state that restains from the involvement in the economic process. These state-developed regulations guard free and fair competition with politically independent institutions (such as the Bundeskartellamt). There is a feedback loop between competitive economic order and individual freedom. Through freedom, the individual can respect moral norms, stabilizing the existing economic order.

Eucken was convinced that the state ought to set the economic order and continuous care, flanked by a long-term guarantee and security of the competition. This should be achieved by reducing barriers to market entry and guaranteed by an active competition policy. On the other hand, the economic process should be left to individual economic entities, which would be achieved by a pricing system that would be coordinated in a decentralized manner. Eucken's theory distinguishes between seven constitutive and four regulatory principles. While the constitutive tenets form the basic framework, the regulatory standards are set as corrective measures, which can be combined with the inadequacy of the principle of competition (Müller, 2019, p. 34). These principles are presented in Table 1.

In Germany, this model has not been fully implemented in practice. This is a warning and a lesson that the advocates of this concept should take into account. Firstly, there needs to be a clearly defined path to achieving it. In the case of countries with a system other than the capitalist one, this route will be longer, requiring a great deal of social effort, including acceptance of the values which, in the social market economy, play a significant role, such as freedom, responsibility for oneself, one's fate and society. The lack of acceptance of these values will mean that policies pursued in this style can be quickly rejected, as was the case during the first post-war recession in Germany in 1967. Another perti- 
nent issue is the pursuit of a thoughtful and constant economic policy that puts individuals and their development at the heart of the matter, thus protecting free competition and private ownership. In addition, emphasis should be placed on building politically independent institutions that protect the market, competition, law, and monetary policy from the pressures of interest groups. As far as the social structure is concerned, care must be taken to develop the middle class, which is at the core of this doctrine, and to develop the importance of trade unions. Still, the critical flaw of this model remains the vagueness the adjective "social" has in this context. Various political parties may give this word inverse interpretations, which inevitably leads to expanding the social security system. Hence, one may encounter different versions of this model. It is hard to disagree with the statement made by the American economist, Berger (1996, pp. 1-29), who wrote: "if the lack of political will to preserve institutions and values that go beyond efficiency and growth, then no national tradition, culture or the legacy of the past can stop market forces. From this point of view, even systems such as the German or Japanese ones are under threat, although they work better in the long term".

\section{Methods}

The problem addressed in this article concerns systemic transformation, the choice of the target economic model and the paths to accomplish the goal. Due to its complex nature and the need to analyze factors that are also qualitative in nature, this challenge canot be subjected to econometric modelling. The analysis uses a method of qualitative analysis, which is the comparative analysis of the Polish and East German economies. Secondary statistical data of the World Bank (2021) and German institutions, Arbeitskreis "VGR der Länder" (2020), were implemented here. The analysis included the review of economic indicators for the period 1991-2019 and institutional factors in terms of chosen formal and informal institutions. Relying on the practice of Central and Eastern European economies, the paper undertakes that the shape of the target economic model of economies undergoing systemic transformation is determined by the initial conditions of the transformation process, the role of the state in this process, and the features of the economic policy pursued.

\section{Results}

\subsection{Course and effects of the systemic transformation in Poland}

As mentioned in the introduction to this study, the reforms selected to be carried out in Poland and other countries of Central and Eastern Europe followed the model of "shock transformation" agreement proposed and financed by the IMF (Kołodko, 2020). In 1989 the British economist John Williamson 
(1990) called this policy the Washington Consensus. Williamson (2004; 2005) sought to isolate its essential features and point out its flaws.

To begin with, the reforms in Poland were inspired by monetarism, stabilizing the economy, and controlling inflation, transforming the economic system, consequently opening up the economy. Due to Poland's hyperinflation since 1989 , the program of stabilization reforms and systemic transformations was introduced in January 1990, the earliest in the group of Central and Eastern European countries. Actions taken based on monetary policy were aimed at slowing down the rapid growth of the nominal money stock and increasing the nominal interest rate. Moreover, a fundamental limitation in the use of preferential loans was envisaged, a one-off change in terms of loan agreements concluded in the past in terms of interest rates, restrictions on the financing of the state deficit by the NBP, and an increase in the political independence of the NBP from the government (Dąbrowski, 1997). Income policy took a restrictive course, thus strengthening the monetary policy.

Another aspect was the institutional transformations, which included liquidation of the remains of the central management system, introduction of local government and municipal property, abandonment of the automatic rule the financing of economic undertakings, the introduction of social protection for the unemployed, 'small' privatization and, which was significant for the development of competition policy, the creation of an Antitrust Office (Dąbrowski, 1997).

The reform package was launched on January 1, 1990. Initially, inflation increased instead of decreasing, but soon it fell systematically (with some exceptions). Within three months, the shortages disappeared, and the shelves were filled. The most tremendous success of the program turned out to be the quick achievement of external balance. Over time, however, the adverse effects of the reforms began to emerge. The first of these was the recession (see Table 2). It originated not in cyclical fluctuations but resulted from a clash between a closed economy and a market economy. The genesis of this recession was composed of internal processes: instability inherited from a centrally planned economy, liberalization processes, and implementation of anti-inflationary policies, which led to a reduction in demand and supply. Those were accompanied by external factors, the breaking of ties with the USSR and COMECON's break-up and the global economy's recession (Bąk, 2006, pp. 83-84).

In the autumn of 1990, inflation started to accelerate again, mainly due to the rise in oil prices following the Iraqi attack on Kuwait. Another factor influencing the growing inflation was the devaluation of the Polish currency on January 1, 1990, from PLN 6,500 for USD 1 to a level lower than the black-market rate: 1 USD=9500 PLN (Dąbrowski, 1997). Since November 1990, the deterioration of the current account balance resulted in the suspension of the IMF stand-by arrangement. In March 1991, as a result of ongoing negotiations, it was agreed to introduce a three-year Extended Fund Facility program, which was the basis for the Paris Club's decision to reduce the Pol- 
ish debt to the governments of the Member States by 50\% (Dąbrowski,1997). In May 1991, it was decided to devalue the zloty by $17 \%$. Given the trade balance deterioration, in October 1991, the NBP decided to change the exchange-rate policy. A crawling peg rate with a monthly devaluation rate of $1.8 \%$ was introduced (Rosati, 1994). The reforms that were carried out and their effects intensified social discontent. In November 1991, elections were held. A new government emerged, with Jan Olszewski as Prime Minister and Balcerowicz leaving the political scene.

Economists have differing opinions in their assessment of the transformation process. Kołodko $(2000 ; 2020)$ directly pointed to the "bullet hole", namely the excessively restrictive nature of the reform programme. Katarzyna Żukrowska (2000) states that despite its various shortcomings, Balcerowicz's strategy was implemented adequately. As a measure of this success, she stated that Poland recorded the highest growth rate in the region since 1992. Simultaneously, these international comparisons illustrate that other countries of Central and Eastern Europe, regardless of the adopted reform strategy, experienced negative consequences related to systemic transformation. However, their scale was often much more significant than those in Poland (Żuchowska, 2012, p. 106).

The positive effects and consequences of the introduction of the stabilization program were spectacular. They changed the Polish economy for a long time:

enterprises have been subjected to external and internal competitive pressures;

- the state budget has been balanced;

- although the price increase remained at a significant level, hyperinflation was suppressed practically within a month, and the previous real danger of a complete disruption of the economic system disappeared;

- the internally convertible zloty has become a standard and stable currency. In the following years, a gradual acceleration of economic growth could be observed, which could be due to the increasing number of private entities that undertook export activities. Inflation was gradually decreasing, which in 2000 amounted to just over $6 \%$ and in subsequent periods fell below $3 \%$ (see Table 2).

Another significant change that could be observed in the Polish economy after the accession to the European Union in 2004 was the increase of the value of the Polish GDP by $80 \%$ (at a rate of approximately $4.2 \%$ on average per year). During the whole period of systemic transformation, Poland occupied in this respect the leading position in the group of new EU member states (similar results were achieved at that time by Slovakia - 73\%, and Romania - 70\%) (Rapacki \& Próchniak, 2021, p. 36). In 2019, the structure of GDP formation consisted of the following parts: $56.9 \%$ were total services $(15.6 \%$ — trade, $6.6 \%$ - transport and storage, $4.8 \%$ - public administration and defence, compulsory social security, $4.2 \%$ - real estate services, $4 \%$ - education, 3.9\% - health care and social assistance and $17.8 \%$ - other services), $22.1 \%$ - industry, $12.1 \%$ taxes less subsidies and 6.8\% — construction (GUS, 2020, p. 34). 
A relatively unfavorable situation persisted in the labour market. The double-digit unemployment rate persisted until the first decade of the 21st century. Its significant decrease occurred only after 2005 and was related to the consequences of Poland's accession to the European Union. In 2019, it stood at 3.3\% and was even lower than the unemployment rate for both parts of Germany combined.

Another significant variable is the share of public debt in GDP, which was below 60\% of GDP between 1995 and 2019. During the same period, average monthly wages in Poland increased from PLN 702 in 1995 to PLN 5167.47 in 2020 (GUS, 2021). According to the World Bank (2017), during most of the transition period, wage growth in Poland was much slower than productivity growth. While labour productivity increased by half, labour income grew by only a third.

Considering the evolution of the Gini coefficient, which indicates how large the income gap is between the highest earners and the poorest, it is essential to note that in Poland between 2004 and 2018, the coefficient fell from 38 to 30.2 This makes Poland, according to the World Bank (2017), a country with one of the lowest Gini coefficients among countries that have become high-income economies since 2000. The highest inequality is in Mazovia, which is explained by the contrast between Warsaw against the rest of the province. Silesia experiences the most minor inequalities, which may be due to high wages in the mining industry. Compared to other European Union countries (average), Poland stands out with lower levels of income disparity, poverty risk and social exclusion and its other selected aspects, such as very low work intensity and deep material deprivation (Graca-Gelert, 2021, pp. 78-79).

\subsection{The systemic transformation and its consequences for the development of the East German economy}

The process of transformation of the German Democratic Republic began with the so-called State Agreement (Staatsvertrag) of May 18, 1990, between the GDR and Germany. Another legal act was the Einigungsvertrag of August 31, 1990. The State Agreement provided for creating a monetary and socio-economic union on the territory of both German states. It contained a provision that established the social market economy as a standard economic order for both parts of Germany. The fundamental decisions related to the transformation of the East German economy resulted from the solutions contained in the above agreement. The impulses of the transformation had theoretical external inspiration coming from West Germany. The adoption of such an option was mainly dictated by social rather than economic considerations. It was feared that if the mass migration of residents from the former GDR to the BRD remained at the same level, it could destabilize the labour market in West Germany.

East Germany was a unique case among Central and Eastern European countries that were undergoing systemic transformation. The East German economic 
system had not undergone any significant changes since the 1970s, and there were no conditions for the creation of sufficiently expansive grassroots entrepreneurship. The central problems of this economy were over-intensive industrialization, shortages in the supply of essential goods and shortages in housing. Therefore, there was no indication that the stability of this system had been affected, and, later on, the participation of East German citizens in the privatization process was truly traceable. The beneficiaries of the privatization process for the assets of the former GDR were West German companies and West German citizens.

Furthermore, which remains of great significance, a socialist system of values prevailed in East German society that had no organized, influential political opposition groups (Kleer, 1999, pp. 16-34). These signals showed a solid connection to the values of socialism, not capitalism, in East German society. Therefore, constructing a capitalist system such as the social market economy was very much in question. The problem of identification with the ideology of socialism, hence, with high expectations of the state and its policies and the lack of identification of the majority of middle-class society shows the results of research carried out among the citizens of Eastern Germany in the years 19931998. The most significant part of the respondents, as many as $61 \%$, attributed themselves to the working class. The social structure of this region had a pyramid structure with a broad base. In West Germany, on the other hand, almost $60 \%$ of the residents identified as the middle class in the period under study, and the general social structure had a typical onion form. (Krause \& Habich, 2000, p. 333). In 2008, this proportion fell to 51\%, but membership of this group in East Germany remained dominant. However, as much as $41 \%$ of the middle class was assigned to it. This shows relatively slow changes in this society (Goebel et al., 2009, p. 138). The Deutsch Bundesbank was responsible for organizing the money exchange process. For the economy, it was essentially about developing more efficient companies who, with competitive products, lay the foundations for create growth and secure employment (Bofinger, 1990).

The exchange rates at which the currency of the former GDR was replaced with the currency of West Germany increased the amount of money in circulation, the competitiveness of businesses was affected, it fell due to an increase in wages and liabilities, the interest rate changed. To a certain extent, these rates have influenced price levels.

Within the framework of an economic union, the system of the social market economy with its constituent elements: private ownership of the means of production, free movement of prices of goods and factors of production according to market rules, competition in the markets, full mobility of people and capital was transferred to the former GDR.

In addition, a significant element was the introduction of a social union in East Germany, and therefore tariff agreements between the parties to the labour market, the co-determination of employees in the company, and the transfer of the West German social security system. 
The immediate problem arising from the introduction of the Social Market Economy system was the regulation of property and ownership that had once been expropriated.

Thus, privatization became one of the most vital issues affecting the speed and effectiveness of the German reunification process. In East Germany, a model of total privatization was adopted, which was intended to be completed by 1993 (indeed, this process was extended to 1994). This meant that what had not been privatized was being eliminated. State policy in this area was mainly based on allowing new businesses to access former national assets while simultaneously withdrawing financial involvement in those businesses that would not meet the requirements of a market economy. However, this approach opened the door to various types of abuse (Stack, 1997). Hence, Treunhandanstalt was created to restructure companies. In fact, this public law institution, which was in its nature a quasi-business concept, fulfilled the objectives set by the law.

The monetary and economic union abruptly exposed the inefficiencies of the GDR economy under market economy conditions. It triggered a cost shock for the economy due to the revaluation of the GDR mark in currency exchange, which had been exacerbated by wage increases. Sales markets in the former Central and Eastern European partner countries and in the accession area collapsed, not least due to the lack of competitiveness of their own product offerings in open markets. Based on the outcomes of the privatization of the former state enterprises and new and market-oriented entrepreneurship, the incipient modernization of production facilities and product ranges, and the renewal and expansion of infrastructure initiated by the state soon over-came the economic divide (Ludwig, 2020, p. 25).

By the mid-1990s, there was a sharp decline in economic growth in East Germany (see Chart 1), and by the mid-1990s, the growth rate of both parts of Germany had equalled. Looking at Chart 1 in the Appendix, it is difficult not to inquire about the roots of those differences in growth rates between East and West Germany since 1991? One possibility is the relationship between East German GDP and the level of transfers to the former GDR. From the reunification until 2003, support for former East Germany totalled more than EUR 1.2 trillion. Public and private net payments of more than 80 billion euros per year (about $4 \%$ of GDP) have at times been the subject of political debate. Concerns have been voiced that these enormous transfers are a significant burden on the economy of the West and at the same time create benefits dependency trap in the Eastern labour market, making its convergence relatively slow (Jansen, 2004). After taking into account the recurring tax measures, it exceeded the East German GDP. Since 1995, East Germany has been included in the West German public finance system. As shown in Chart 1. after the boom of 2000, the old federal state became more dependent on the world economy, and the German economy gained momentum again. During a severe recession following the financial crisis in 2008/2009, production fell in both parts of the region. In the West, due to its dependence on exports, it was slightly lower 
than in the east of the German economy. As a consequence of implementing the two business cycle programmes, Germany's economic growth accelerated, and the following years saw a slow synchronization of this rate until it levelled off in 2019. It should be noted that the western part of Germany remains more dependent on exports than the eastern part.

During the first two years of the transformation process, due to emigration, the population in East Germany decreased by around 2\%. The level of unemployment started to rise sharply and reached around 17.6 in 2005 (see Table 3 ). Between the reunification of Germany and 2006, the unemployment rate in East Germany was two tonnes higher than in West Germany, and the observed economic recovery did not make the queues at the East German employment offices vanish.

The factor which significantly contributed to the fall in employment was a significant increase in wages, but this was not accompanied by an increase in labour productivity or demand for East German industrial products. During the first six years of transition in East Germany, net wages and salaries first increased by $30.7 \%$ in 1991 and in 1997 to $85.4 \%$ of the West German level. The growth rate in labour productivity between 1991 and 1999 increased more slowly than wages and salaries (Brenke et al, 1999, p. 6).

A facet that needs to be highlighted when analyzing the systemic transformation in East Germany is the significant role of the state and its financial and institutional support.

In purely market-based conditions, East Germany as a production location would hardly have had an opportunity to succeed. Neither would have the East German production, which had been handed down from the GDR era competitive. Production from East Germany safeguards (at least in so far as it was not aimed at purely local goods) the demand for goods in East Germany. The monetary union, which was a prerequisite for this was that, in addition to the Deutschmark, other vital institutions in West Germany were transferable to East Germany.

\section{Discussion}

The Social Market Economy is associated with the specific role of the state, close to institutional capitalism, but alien to Anglo-Saxon thought. The state in this approach prevents market abuse, protects free competition, lays the foundations for economic growth, and develops social capital. The evolution of the Polish system towards the Social Market Economy emerged as one of the Round Table agreements in 1989. As Kołodko (2020) notes, to this day, there has been no clarity, even in theory, as to the definition of the concept, and it has been a source of endless debate about it within the political sphere. In Poland, the nature of the reforms carried out in the first few years of the transformation process showed that a neo-liberal approach prevailed in economic policy and was favourable to it. Despite their declarations, Tadeusz Mazowiecki's government steered 
the state's economic policy in a completely different direction, more reminiscent of the neo-liberal style than the inclusive style found in the Social Market Economy model. It must be clearly stated that in the literature on the subject, one can find opinions indicating that T. Mazowiecki did not perceive the specificity of ordoliberalism, which has been one of the directions of contemporary liberalism and has been located alongside the mainstream of modern neoliberal economics. The reason for this was the significant dissimilarities between ordoliberalism and other liberal orientations (Przybyciński, 2010, p. 171). However, ordoliberalism seems to be closer to conservatism than to neoliberalism since, as the philosopher Krąpiec (2002, p. 379) points out, freedom, including economic freedom, is considered a means of achieving the objective of building economic order. In the neoliberal hierarchy of values, economic freedom comes first and is an end in itself.

The neoliberal strategy of economic transformation in Poland tried to eliminate inflation and make a rapid transition from a centrally planned economy to a market economy, without a transition period and a gradual rethinking of economic mechanisms. It was hoped that market automatism would be immediately incorporated (Przybyciński, 2010, p. 171). However, one cannot ignore the achievements of the stabilization policy of the 1990s, which de facto created stable foundations for the further development of the Polish economy. If we consider W. Eucken's constitutive principles, it must be stressed that, apart from the last principle, which recommends stability in economic policy, all the others have been fulfilled in the Polish economy. The creation of an independent central bank and the establishment of an Antimonopoly Office (Urząd Ochrony Konkurencji i Kosumentów) on the model of the Bundeskartellamt, which guards the observance of antimonopoly law and the protection of competition, are also noteworthy. For many years, Poland has had the reputation of a business-friendly country with a large internal market, competitive business conditions such as low labour costs, a significant and qualified workforce, a favourable geographical location, and pursuit of an essentially reasonable and stable macroeconomic policy. This has resulted in an impressive GDP growth rate observed since the beginning of the systemic transformation. Since 1992 Poland has been developing the fastest in the European Union. The average annual growth of Poland's GDP in the years 1992-2019 was 4.2\%. During the financial crisis in 2007-2009, Poland was the only EU country that avoided recession. This was due, among other things, to the government's rather loose fiscal policy, combined with a commitment to reduce spending in the medium term and a floating exchange rate.

There has been no public space for a serious debate among economists about the provision in the constitution referring to the German model. In Poland, Social Market Economy is a political slogan employed by successive governments. Moreover, Polish economists have, so far, failed to develop a coherent concept of the Social Market Economy for Poland that could be comprehensively imple- 
mented into economic policy. Therefore, the provision in the Polish constitution seems to be still declarative.

The Social Market Economy model implemented in East Germany is not the same model Ludwig Erhard supported and tried to build after World War II. The framework of economic life that was once implemented in the former GDR has evolved over many years. Eastern Germany did not have to develop its own institutional framework. Eastern German society did not have to adapt with such difficulty to the new economic situation and did not take an active role in the privatization process. To a much lesser extent, it was also willing to take responsibility for its life and its living conditions into its own hands. The fact that the value system and principles on which the Social Market Economy is based was not close to the value system of that society remains an important issue. The majority of the region's citizens identifying with the working class and expectations of state policy continue to demonstrate the influence of socialist ideas. There was a lack of entrepreneurial spirit in society, which was linked to the marginal role of private property in the GDR, so crucial to the social market economy. West German standards were introduced in East Germany without considering the needs of this economy, namely, some aspects of flexibility and adaptation to the specific economic conditions and a focus on developing its innovation and competitiveness. The state's role in this process was not limited to an entity creating the conditions for society's development but as a promoter of all development and financial support. When analysing, for example, the reconstruction of West Germany after the Second World War, it is clear that economic success is not just about favourable external conditions and financial aid under the Marshall Plan, but about the consistency of the determination and effort of the whole of society, which could use its initiative on a complimentary basis.

\section{Conclusion}

The transformation process that began in Central and Eastern European countries in the early 1990s, including Poland and the German Democratic Republic, made it necessary to choose the model to which these economies would be heading. Both countries opted for a social market economy at different points in time. The German Democratic Republic adopted the SME model and the entire institutional and legal apparatus from West Germany. The shock caused by the transformation and the further development of events showed that the initial conditions in which the East German economy found itself differed from those that took place in West Germany after 1945 and that the society of the former GDR is instilled with entirely different values than those on which the model of the social market economy is based. The process of transformations was much more painful and lengthy than assumed. Moreover, the state's role in developing the East German economy significantly exceeded its role by the doctrine of the Social Market Economy, imposing a rigid institutional structure not 
adapted to the economy undergoing transformation and financial transfers trying to stimulate the development of the East German economy.

The systemic transformation in Poland was carried out based on a monetarist vision of the stabilization policy, which does not have much in common with the German approach. Nevertheless, the effects of the transformation enabled the creation of stable foundations for developing the Polish economy and achieving a leading position among Central and Eastern European countries. Poland and East Germany share the experience of a centrally planned economy. Yet, the mode of the system transformation implemented in each country was completely different, thus resulting in each country being at a unique point on the path of economic development. Neither country has been able to implement a social market economy model the way its spiritual fathers perceived it. Perhaps each country should create a social market economy model on its own, tailored to the specific economic conditions in that country. However, this requires specific action at various levels, state and local government, and cooperation between academia and business.

\section{References}

Arbeitskreis "VGR der Länder" (2020). Retrieved 13.07.2021 from https:// www.statistikportal.de/de/vgrdl/publikationen.

Bąk, M. (2006). Europa Środkowa i Wschodnia wobec wyzwania transformacyjnego. Uniwersytet Gdański.

Berger, S. (1996). Introduction. In S. Berger \& R. Dore (Eds.), National diversity and global capitalism (pp. 1-29). Cornell University Press. https://doi. org/10.7591/9781501722158-002.

Bofinger, P. (1990). The German monetary unification (GMU): converting marks to D-Marks. Federal Reserve Bank of St. Louis Review, 72(4), 17-36. https://doi.org/10.20955/r.72.17-36.

Brenke, K., Eickelpasch, A., Postlep, R.-D., Gerling, K., Sander, B., Schmidt, K.-D., Beer, S., Bergemann, A., Komar, W., Müller, R., Ragnitz, J., Traben, L. (1999). Gesamtwirtschaftliche und unternehmerische Anpassungs-fortschritte in Ostdeutschland: Neunzehnter Bericht. Kieler Diskussionsbeiträge, 346/347, 1-193.

Dąbrowski, M. (1997). Fiscal policy in Poland under transition. Russian and East European Finance and Trade, 6(33), 5-66.

Eucken, W. (1992). The foundations of economics: history and theory in the analysis of economic reality. Springer. https://doi.org/10.1007/978-3-642-77318-1.

Eucken, W. (2004). Grundsätze der Wirtschaftspolitik. Mohr Siebeck.

Goebel, J., Habich, R., Krause, P. (2009). Zur Angleichung von Einkommen und Lebensqualität im vereinigten Deutschland. Vierteljahrshefte zur Wirtschaftsforschung, 78(2), 122-145. 
Graca-Gelert, P. (2021). Zróżnicowanie dochodów, zagrożenie ubóstwem oraz inne wybrane aspekty wykluczenia społecznego w Polsce na tle krajów Unii Europejskiej. In A.M. Kowalski, \& M.A. Weresa (Eds.), Polska: raport o konkurencyjności 2021: bilateralna wspótpraca gospodarcza a przewagi konkurencyjne (pp. 49-80). SGH.

GUS. (2020). Polska w liczbach 2020. Retrieved 11.07.2021 from https://stat.gov. $\mathrm{pl} /$ download/gfx/portalinformacyjny/pl/defaultaktualnosci/5501/14/13/1/ polska_w_liczbach_2020_pl.pdf.

GUS. (2021). Przeciętne miesięczne wynagrodzenie $w$ gospodarce narodowej w latach 1950-2020. Retrieved 13.07.2021 from https://stat.gov.pl/ obszary-tematyczne/rynek-pracy/pracujacy-zatrudnieni-wynagrodzenia-koszty - pracy/przecietne - miesieczne - wynagrodzenie-w - gosp odarce-narodowej-w-latach-1950-2020,2,1.html.

Jansen, H. (2004). Transfers to Germany's eastern Länder: a necessary price for convergence or a permanent drag. ECFIN Country Focus, 1(16), 1-6.

Kaczmarek, T.T., \& Pysz, P. (2004). Ludwig Erhard $i$ spoteczna gospodarka rynkowa. PAN.

Kamińska, K. (2018). Ordoliberalizm i keynesizm: dwie sprzeczne koncepcje w polityce gospodarczej powojennych Niemiec. UOKiK.

Karsten, S. (1985). Eucken's ,social market economy' and its test in post-war west Germany: the economist as social philosopher developed ideas that parallelled progressive thought in America. The American Journal of Economics and Sociology, 44(2), 169-183. https://doi.org/10.1111/j.1536-7150.1985. tb02331.x.

Kleer, J. (1999). Niemcy Wschodnie a teoria transformacji. In W. Małachowski (Ed.), Polska-Niemcy a gospodarka rynkowa (pp. 18-35). SGH.

Klump, R. (2001). Soziale Marktwirtschaft: Geistige Grundlagen, ethischer Anspruch, historische Wurzeln. In O. Schlecht, \& G. Stoltenberg (Ed.), Soziale Marktwirtschaft. Grundlagen, Entwicklungslinien, Perspektiven (pp. 1759). Verlag Herder.

Kołodko, G. (2000). From shock to therapy: the political economy of postsocialist transformation. Oxford University Press. https://doi.org/10.1093/acprof: oso/9780198297437.001.0001.

Kołodko, G. (2020). Economics and politics of post-communist transition to market and democracy: the lessons from Polish experience. Post-Communist Economies, 32(3), 285-305. https://doi.org/10.1080/14631377.2019.16 94604.

Kouba, L. (2016). A lesson for the contemporary European, periphery from the transition process of the CEE countries. In P. Huber, D. Nerudová, \& P. Rozmahel (Eds.), Competitiveness, social inclusion and sustainability in a diverse European Union: perspectives from old and new member states (pp. 163-178). Springer. https://doi.org/10.1007/978-3-319-17299-6_9.

Krause, P., \& Habich, R. (2000). Einkommen und Lebensqualität im vereinigten Deutschland. Vierteljahrshefte zur Wirtschaftsforschung, 69(2), 316-340. 
Krąpiec, M. (2002). Powszechna encyklopedia filozofii. Polskie Towarzystwo Tomasza z Akwinu.

Ludwig, U. (2020). Mikrofundierte makroökonomische Resultate der ostdeutschen Transformationswirtschaft. In Ostdeutschland. Eine Bilanz (pp. 16-35). Leibnitz Institute für Wirtschaftsforschung.

Maier, C.S. (2012). The travails of unification: east Germany's economic transition since 1989. In G. Roland (Ed.), Economies in transition: studies in development economics and policy (pp. 344-363). Palgrave Macmillan. https://doi. org/10.1057/9780230361836_14.

Müller, M.H-P. (2019). Neo-Ordoliberalismus: Ein Zukunftsmodell für die Soziale Marktwirtschaft Springer. https://doi.org/10.1007/978-3-658-21883-6.

Müller-Armack, A. (1978). The social market economy as an economic and social order. Review of Social Economy, 36(3), 325-331. https://doi. org/10.1080/00346767800000020.

Przybyciński, T. (2010). Etyka a kształtowanie rynkowego ładu gospodarczego w Polsce. Annales: Etyka w życiu gospodarczym, 13(1), 167-175.

Rapacki, R., \& Próchniak, M. (2021). Rozwój gospodarki polskiej w latach 2010-2020 na tle innych krajów UE i wybranych partnerów gospodarczych Polski. In A.M. Kowalski, \& M.A, Weresa (Eds.), Polska: raport o konkurencyjności 2021: bilateralna wspótpraca gospodarcza a przewagi konkurencyjne (pp. 29-48). SGH.

Rosati, D. (1994). Output decline during transition from plan to market. Economies of Transition, 2(4), 419-441. https://doi.org/10.1111/j.1468-0351.1994. tb00126.x.

Sachs, J. (1993). Poland's jump to the market economy. MIT Press. https://doi. org/10.7551/mitpress/5430.001.0001.

Stack, H.M. (1997). The "colonization" of east Germany: a comparative analysis of German privatization. Duke Law Journal, 46(5), 1211-1253. https://doi. org/10.2307/1372919.

Williamson, J. (1990). What Washington means by policy reform. In J. Williamson (Ed.), Latin American adjustment: how much has happened (pp. 5-38). Institute for International Economies.

Williamson, J. (2004). The Washington consensus as policy prescription for development. Retrieved 29.03.2021 from: https://www.piie.com/publications/ papers/williamson0204.pdf.

Williamson, J. (2005). Differing interpretations of the Washington consensus. Leon Kozminski Academy of Entrepreneurship and Management and TIGER Distinguished Lectures Series, 17, 1-23.

World Bank. (2017). Lessons from Poland, insights for Poland: a sustainable and inclusive transition to high income status. Retrieved 13.07.2021 from https://openknowledge.worldbank.org/handle/10986/28960.

World Bank. (2021). Retrieved 22.11.2020 from https://data.worldbank.org.

Zagóra-Jonszta, U. (1999). Ordoliberalizm a spoteczna gospodarka rynkowa Niemiec: możliwości jej realizacji w Polsce. Akademia Ekonomiczna w Katowicach. 
Żuchowska, D. (2012). Polityka kursu walutowego a inflacja w krajach Europy Środkowo-Wschodniej. CeDeWu.

Żukrowska, K., (2000). Poland: an effective strategy of systemic change. In W. Kostecki, K. Żukrowska, \& B. Góralczyk (Eds.), Transformations of post-communist states (pp. 168-184). Palgrave Macmillan. https://doi. org/10.1057/9780230511309_10.

\section{Acknowledgements}

Author contributions: author has given an approval to the final version of the article.

Funding: this research was undertaken as part of the project 30 years after the system transformation: lessons and current challenges for the economy in Germany and Poland and was fully funded by the SGH Warsaw School of Economics.

Note: the results of this study were presented at llth International Conference on Applied Economics Contemporary Issues in Economy (June 17-18, 2021, online, Poland). 


\section{Appendix}

\section{Table 1.}

\section{Competitive economic order principles}

\begin{tabular}{|c|c|}
\hline Constitutive principles & Regulatory principles \\
\hline $\begin{array}{l}\text { - an excellent competitive pricing system that ade- } \\
\text { quately serves as an indicator of the scarcity of goods } \\
\text { and resources; }\end{array}$ & $\begin{array}{l}\text { - where natural and local monopolies exist; } \\
\text { - where there are socially unacceptable income differ- } \\
\text { ences; }\end{array}$ \\
\hline $\begin{array}{l}\text { - stabilising the purchasing power of money; } \\
\text { - open markets; }\end{array}$ & $\begin{array}{l}\text { - where the economic accounts of undertakings do not } \\
\text { include externalities; }\end{array}$ \\
\hline $\begin{array}{l}\text { - private ownership of means of production; } \\
\text { - freedom to conclude contracts between economic } \\
\text { operators; }\end{array}$ & $\begin{array}{l}\text { - where there is abnormal behaviour on the supply } \\
\text { side, including labour supply. }\end{array}$ \\
\hline $\begin{array}{l}\text { - material liability of economic operators for damage } \\
\text { caused to others; }\end{array}$ & \\
\hline - the stability and consistency of economic policy. & \\
\hline
\end{tabular}

Source: Eucken (2004, pp. 225-301).

Table 2.

Selected macroeconomic indicators of Poland in 1990-2019

\begin{tabular}{lrrrrrrrrrr}
\hline \multicolumn{1}{c}{ Indicator } & \multicolumn{1}{c}{1990} & \multicolumn{1}{c}{1991} & \multicolumn{1}{c}{1992} & 1993 & 1995 & 2000 & 2005 & 2010 & 2015 & 2019 \\
\hline GDP growth rate (in \%) & -7.17 & -7.01 & 2.5 & 3.7 & 6.9 & 4.56 & 3.49 & 3.6 & 3.84 & 4.1 \\
inflation (in \% of GDP) & 86.54 & 55.26 & 38.6 & 30.6 & 27.97 & 6.11 & 2.56 & 1.66 & 0.77 & 2.95 \\
unemployment rate (in\%) & 6.3 & 11.8 & 13.6 & 14.39 & 13.69 & 16.31 & 17.7 & 9.6 & 7.5 & 3.3 \\
\hline
\end{tabular}

Source: World Bank (2021).

Table 3.

Selected macroeconomic indicators of the Eastern German economy from 1990-2019

\begin{tabular}{lrrrrrrr}
\hline \multicolumn{1}{c}{ Years } & \multicolumn{1}{c}{1991} & \multicolumn{1}{c}{1995} & \multicolumn{1}{c}{2000} & 2005 & 2010 & \multicolumn{1}{c}{2015} & 2018 \\
\hline nominal GDP (in million euro) & 107373 & 206981 & 231439 & 253211 & 285630 & 337297 & 372308 \\
domestic labour force (in 1 000 persons) & 6787 & 6105 & 6008 & 5670 & 5882 & 5892 & 6017 \\
employed residents (in 1 000 persons) & 6994 & 6320 & 6358 & 6059 & 6294 & 6258 & 6330 \\
employment rate (in \%) & 47.8 & 44.7 & 46.1 & 45.8 & 49.7 & 49.9 & 50.3 \\
unemployment rate (in \%) & 10.6 & 13.3 & 16.4 & 17.6 & 11.0 & 8.5 & 6.9 \\
\hline
\end{tabular}

Source: World Bank (2021). 
Chart 1.

GDP growth rate between 1991 and 2019 in East Germany, West Germany, and Germany together (in \%)

15

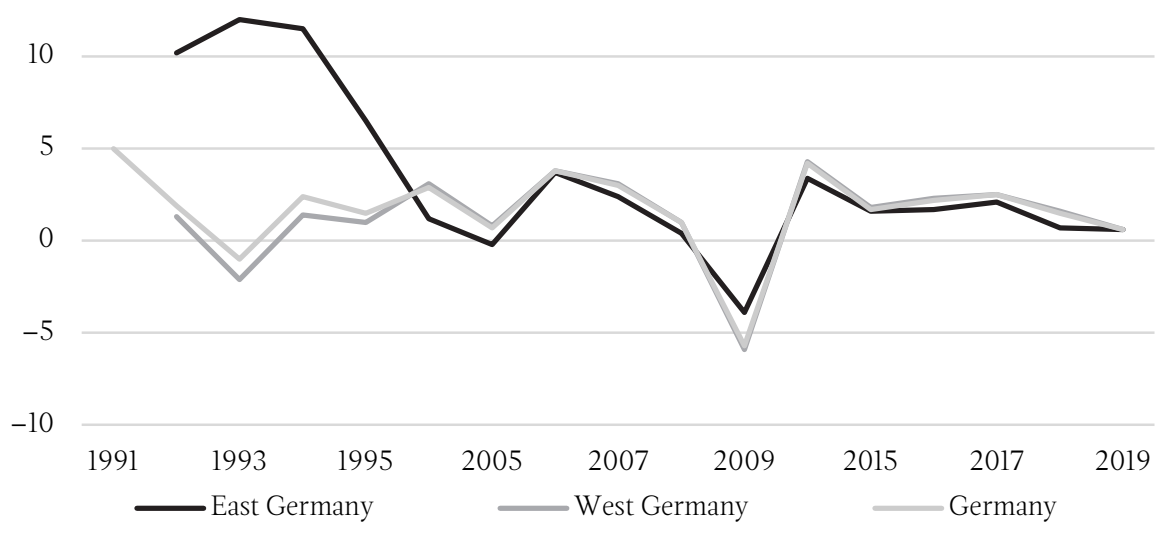

Source: Own preparation based on Arbeitskreis "VGR der Länder" (2020). 